\title{
To the morphology and synonymy of insufficiently known Melittia rutilipes Walker, 1865 [“1864”] (Lepidoptera: Sesiidae)
}

\author{
К морфологии и синонимии недостаточно известного Melittia \\ rutilipes Walker, 1865 [“1864”] (Lepidoptera: Sesiidae)
}

\author{
O.G. Gorbunov \\ О.Г. Горбунов
}

\begin{abstract}
A.N. Severtsov Institute of Ecology and Evolution, Russian Academy of Sciences, Leninsky prospekt 33, Moscow 119071, Russia. E-mail: gorbunov.oleg@mail.ru

Институт проблем экологии и эволюции им. А.Н. Северцова РАН, Ленинский проспект 33, Москва 119071, Россия.
\end{abstract}

KEY WORDS: Melitiini, Melittia moluccaensis, systematics, new synonym, Oriental Region.

КЛЮЧЕВЫЕ СЛОВА: Melitiini, Melittia moluccaensis, систематика, новый синоним, Ориентальный регион.

ABSTRACT. The specimens of the genus Melittia Hübner, 1819 ["1816"] collected on Bacan Island (North Maluku, Indonesia) made it possible to establish that Melittia rutilipes Walker, 1865 ["1864"] is a senior synonym for M. moluccaensis Hampson, 1919. Figures of the male genitalia of $M$. rutilipes Walker, 1865 ["1864"] are shown for the first time. Data on the flight period, biotope and distribution of $M$. rutilipes are presented.

РЕЗЮМЕ. Собранные на острове Бачан (Северное Малуку, Индонезия) экземпляры рода Melittia Hübner, 1819 [“1816”] позволили установить, что Melittia rutilipes Walker, 1865 [“1864”] является старшим синонимом M. moluccaensis Hampson, 1919. Впервые приведено изображение гениталий самца M. rutilipes Walker, 1865 [“1864”]. Приведены данные о сроках лёта, биотопе и распространению $M$. rutilipes.

\section{Introduction}

The genus Melittia Hübner, 1819 ["1816"] is the largest sesiid genus of the tribe Melitiini. Currently, it concludes up to 97 species [Bartel, 1912; Hampson, 1919 (part); Dalla Torre, Strand, 1925 (part.); Gaede, 1929 (part.); 1933; Heppner, Duckworth, 1981(part.); Arita, Yata, 1987; Gorbunov, Arita, 1995, 1996, 1997, 1999; Arita, Gorbunov, 1995, 1996a, b, 1997, 2000, 2001, 2002; Špatenka et al., 1999; Arita, Kallies, 2000; Kallies, Arita, 2003, 2004; Arita et al., 2004; Pühringer, Kallies, 2004 (part.); Gorbunov, 2014, 2015, 2017; Bartsch, 2016; Kallies et al., 2016; Liang, Hsu,
2017; Moreira et al., 2019; own results]. The genus occurs in the Afrotropical, eastern part of Palaearctic (China, Korea and Japan), Oriental and Australian Regions.

During a short-time trip to North Maluku, Indonesia in February-March 2017, I could collect several very interesting species of Sesiidae with the help of artificial sex attractants produced by PHEROBANK ${ }^{\circledR}$, Wijk bij Duurstede, the Netherlands. One of the collected species was a representative of the genus Melittia Hübner, 1819 ["1816"]. Following a detailed analysis of external morphology, it turned out to be $M$. rutilipes Walker, 1865 ["1864"], which was described directly from this island. The female holotype of this species was revised by Arita and Gorbunov [1995], but its male remained unknown. Further, after carefully studying the habitus of the collected specimens and comparing them with the holotype of $M$. moluccaensis Hampson, 1919 (Fig. 1), which was also described from the island of Bacan, I came to the conclusion that they are conspecific and here I establish a new synonym of Melittia rutilipes Walker, 1865 [“1864"] = Melittia moluccaensis Hampson, 1919, syn.n.

The descriptions of specimens were made using a Leica EZ4 stereomicroscope with LED illuminations. Images of freshly collected moths and their habitat were taken with a Sony ${ }^{\circledR} \alpha 450$ DSLR camera equipped with a Minolta $^{\circledR} 50 \mathrm{f} / 2.8$ Macro lens. The figures of the specimens from museums and their labels were scanned using a Nikon ${ }^{\circledR}$ LS 2000 Cool Scan from Ektachrome ${ }^{\circledR}$ slides. The genitalia were photographed using a Keyence ${ }^{\circledR}$ BZ-9000 Biorevo Fluorescence Microscope. The processing of all illustrations was finalized with Adobe ${ }^{\circledR}$ Photoshop $^{\circledR} 2020$ software.

How to cite this article: Gorbunov O.G. 2020. To the morphology and synonymy of insufficiently known Melittia rutilipes Walker, 1865 [“1864”] (Lepidoptera, Sesiidae) // Russian Entomol. J. Vol.29. No.1. P.87-92. doi: 10.15298/rusentj.29.1.12 
The material studied or mentioned herein is kept in the following collections: BMNH - the Natural History Museum, London, UK; COGM - the collection of the A.N. Severtsov Institute of Ecology and Evolution of the Russian Academy of Sciences, Moscow, Russia; OUZM - Oxford University Museum of Natural History (Zoological Collections), Oxford University, Oxford, UK.

All synonymic names in the text are given in quotation marks, in the same way as they are presented in the original descriptions. All labels of the holotype of $M$. rutilipes are cited verbatim. Each label is separated by semicolon marks (;), while lines on a label are shown separated by a slash ("/"). Pictures of the specimens are labeled with a number which consists of the name of the family, two consecutive digits and a year (e.g., SESIIDAE pictures №№ 0011-0012-2017). These numbers correspond to those of the illustrated specimens in the archives of the author. All dissected genitalia are placed in a microtube and pinned under the specimen. The genitalia number is also printed on a label (e.g., Preparation № OG-005-2018), pinned under the specimen and listed in the archives of the author.

\section{Taxonomic account}

\section{Melittia rutilipes Walker, 1865 [“1864”] * Figs 1-11.}

"Melittia rutilipes." — Walker, 1865: 16. Type locality: "Batchian." [= Indonesia: North Maluku, Bacan Island]. Holotype + (OUZM).

$=$ "Melittia moluccaensis n. sp." - Hampson, 1919: 89. Type locality: "Batchian (Waterstradt), 20 type in Coll. Rothschild, Buru (Doherty), 1 o , 1 in Coll. Rothschild.” [= Indonesia: North Maluku, Bacan Island]. Syntype $\sigma^{7}$ (BMNH), syn.n.

Literature. Boisduval, 1875: 471 (Melittia rutilipes); Swinhoe, 1892: 37 (Melittia rutilipes); Hampson, 1919: 87 (Melittia rutilipes); Dalla Torre, Strand, 1925: 146 (Melittia moluccaensis), 148 (Melittia rutilipes); Gaede, 1933: 788 (Melittia rutilipes), 789 (Melittia moluccaensis); Heppner, Duckworth, 1981: 27 (Melittia moluccaensis, Melittia rutilipes); Arita, Gorbunov, 1995: 196, figs 7-8, 22, 26 (Melittia rutilipes), 197 (Melittia moluccaensis); Pühringer, Kallies, 2004: 17 (Melittia moluccaensis, Melittia rutilipes).

MATERIAL. 1 ( (holotype of Melittia rutilipes) with labels: "Bac." (white circle); "Wallace" (white)"; "A Walker's / Type / Melittia / rutilipes" (white); "2 / F. Le Cerf" (white); "150" (white); "Genitalia examined by / O. Gorbunov \& Y. Arita / Preperation No. GA-092” (white); "HOPE ENT. COLL. / OXF. UNIV. MUS. / GENITALIA NO.: / 1552/1955" (white); "TYPE LEP.: No. 57 / Melittia / rutilipes / Walker / HOPE DEPT. OXFORD” (white); "HOLOTYPUS + / Melittia rutilipes / Walker, [1865] / O. Gorbunov \& / Y/ Arita rev., 1994" (red) (OUZM); $1 \sigma^{7}$ (holotype of Melittia moluccaensis) (Fig. 1) with labels as in Fig. 2 (BMNH); 1 + (Fig. 3) with labels as in Fig. 4 (BMNH); $2 \sigma^{7} \sigma^{7}$ (Figs 5-8), Indonesia, North Maluku, Bacan Id., Labuha, 00³9.390’ N, $127^{\circ} 30.042^{\prime} \mathrm{E}, 118 \mathrm{~m}, 28 . \mathrm{II} .2017$, O. Gorbunov leg. (Sesiidae pictures №№ 0009-0012-2017) (1 $\sigma^{\top}$ with genitalia preparation № OG-054-2018) (COGM).

DESCRIPTION. Male (Figs 7-8). Alar expanse 31.0 $\mathrm{mm}$, body length $16.8 \mathrm{~mm}$, forewing $13.5 \mathrm{~mm}$, antenna 6.9 $\mathrm{mm}$.

* The date on the title page of the $31^{\text {st }}$ issue of this Walker's work is 1864, but, in accordance with the opinion of Nye [1975: 7], its printed part was submitted to and approved by the Trustees of the British Museum on February $11^{\text {th }} .1865$.
Head with antenna black with dark violet sheen dorsally and brown to light brown ventrally, scapus dark brown to black with a few dark yellow scales externally; frons graybrown with violet sheen; labial palpus black with dark violet sheen and a dense admixture of dark orange scales; vertex mixed with black and dark orange hair-like scales; pericephalic hairs mixed with black and dark orange hair-like scales dorsally and dark yellow laterally.

Thorax with patagia dark brown to black with dark blueviolet sheen; tegula dark brown to black with dark violet sheen and a few dark orange scales laterally; meso- and metathorax dark brown to black with dark violet sheen and a few dark orange hair-like scales posterior-laterally; laterally thorax gray-brown with bronze-violet sheen; posteriorly both metepimeron and metameron gray densely covered with long gray hair-like scales with yellowish hue. Legs with neck plate black with bronze-violet sheen; fore coxa black with dark violet sheen and a few dark yellow-orange scales medially; fore femur black with dark violet sheen, a narrow orange anterior margin and a few dark yellow scales posteriordistally; fore tibia black with dark violet sheen dorsally and dark orange ventrally; fore tarsus dark orange with a few black scales with dark violet sheen dorsally and dark yellow with golden hue ventrally; mid coxa dark gray-brown to black with dark violet sheen; mid femur black with dark blue-violet sheen, a narrow orange anterior margin and a few dark orange scales exterior-distally; mid tibia black with dark violet sheen and an admixture of dark orange scales exterior-medially; spurs black with dark violet sheen mixed with dark orange scales internally; mid tarsus black with dark violet sheen and a dense admixture of orange scales dorsally and dark yellow ones ventrally; hind coxa dark gray-brown to black with dark violet sheen; hind femur black with dark blue-violet sheen, a narrow orange anterior margin and a few dark orange scales exterior-distally; hind tibia black with dark violet sheen, a dense admixture of dark orange scales dorsally and a narrow, oblique, dark orange stripe in basal third externally; spurs black with dark violet sheen mixed with dark orange scales internally; hind tarsus black with dark violet sheen, am admixture of dark orange scales dorsally and a narrow dark orange stripe externally. Forewing dorsally black with anthracite sheen at base; costal and anal margins, $\mathrm{CuA}$-stem, veins within external transparent area and apical area dark brown to black with dark violet sheen and a few brownish scales; discal spot dark brown to black with dark violet sheen and a few brownish scales, broad, triangular, with a long and narrow projection proximally; transparent area poorly developed and densely covered with semitransparent scales with brownish hue; anterior transparent area narrow and short; posterior transparent area not reaching level of distal margin of discal spot; external transparent area trapeziform, divided into four cells between veins $\mathrm{R}_{4+5}$ and $\mathrm{CuA}_{1}$ narrower costally and broader anally; ventrally opaque parts dark brown with dark violet sheen and a few dark orange scales on discal spot medially; cilia dark brown with dark violet sheen. Hindwing transparent with brownish hue; dorsally veins, discal spot, outer margin and anal lobe dark brown to black with dark violet sheen; discal spot extremely small, triangular, reaching to base of vein $\mathrm{M}_{2}$; outer margin narrow, about 0.5 times as broad as cilia; ventrally veins, discal spot and outer margin dark brown to brown with bronze-violet sheen; cilia dark brown with dark violet sheen.

Abdomen dorsally black with dark violet sheen; distal row of scales of each tergite dark gray-brown with bronzeviolet sheen and a few orange scales on tergites 2, 4 and 7 laterally; ventrally dark gray-brown with blue-violet sheen; 

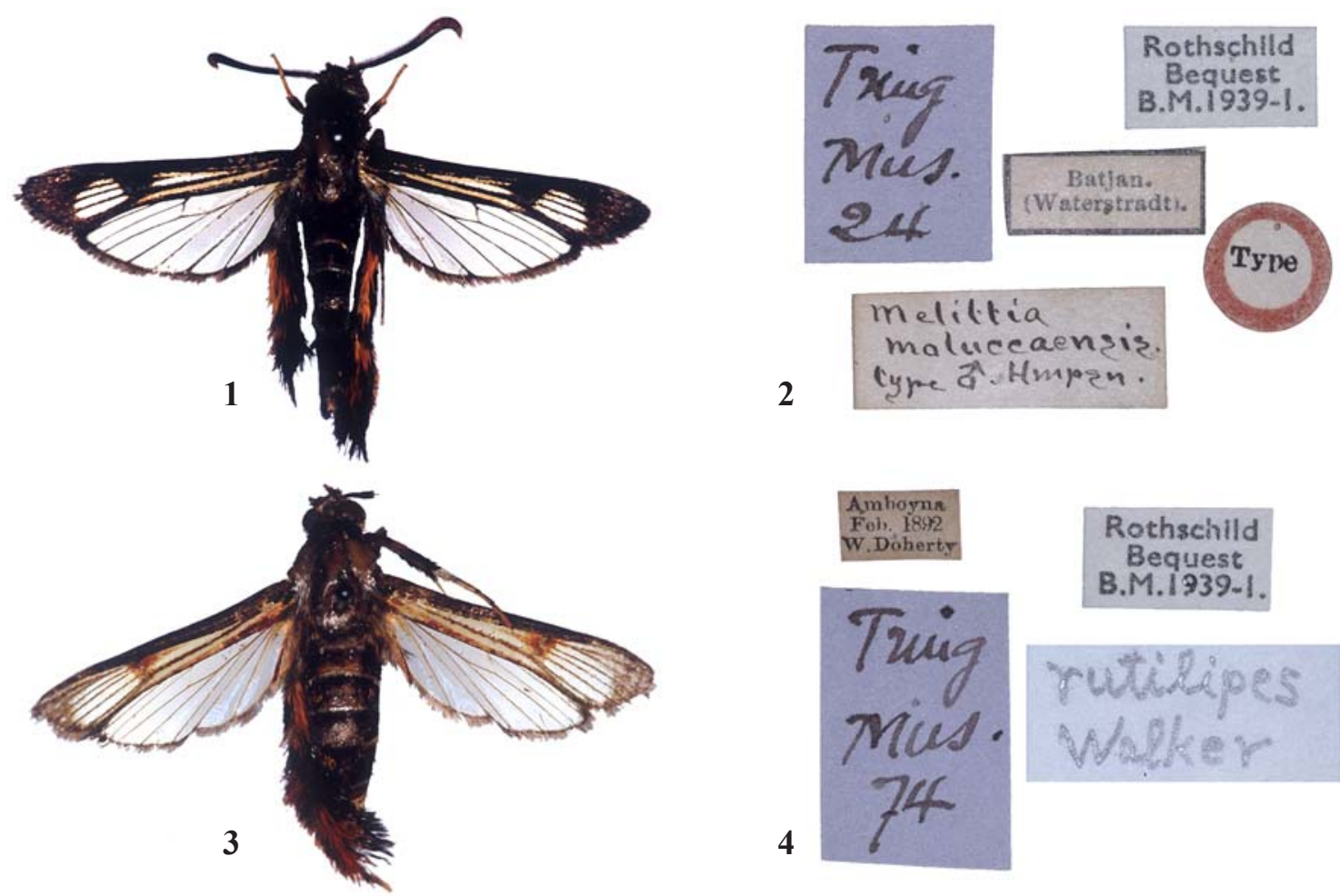

2
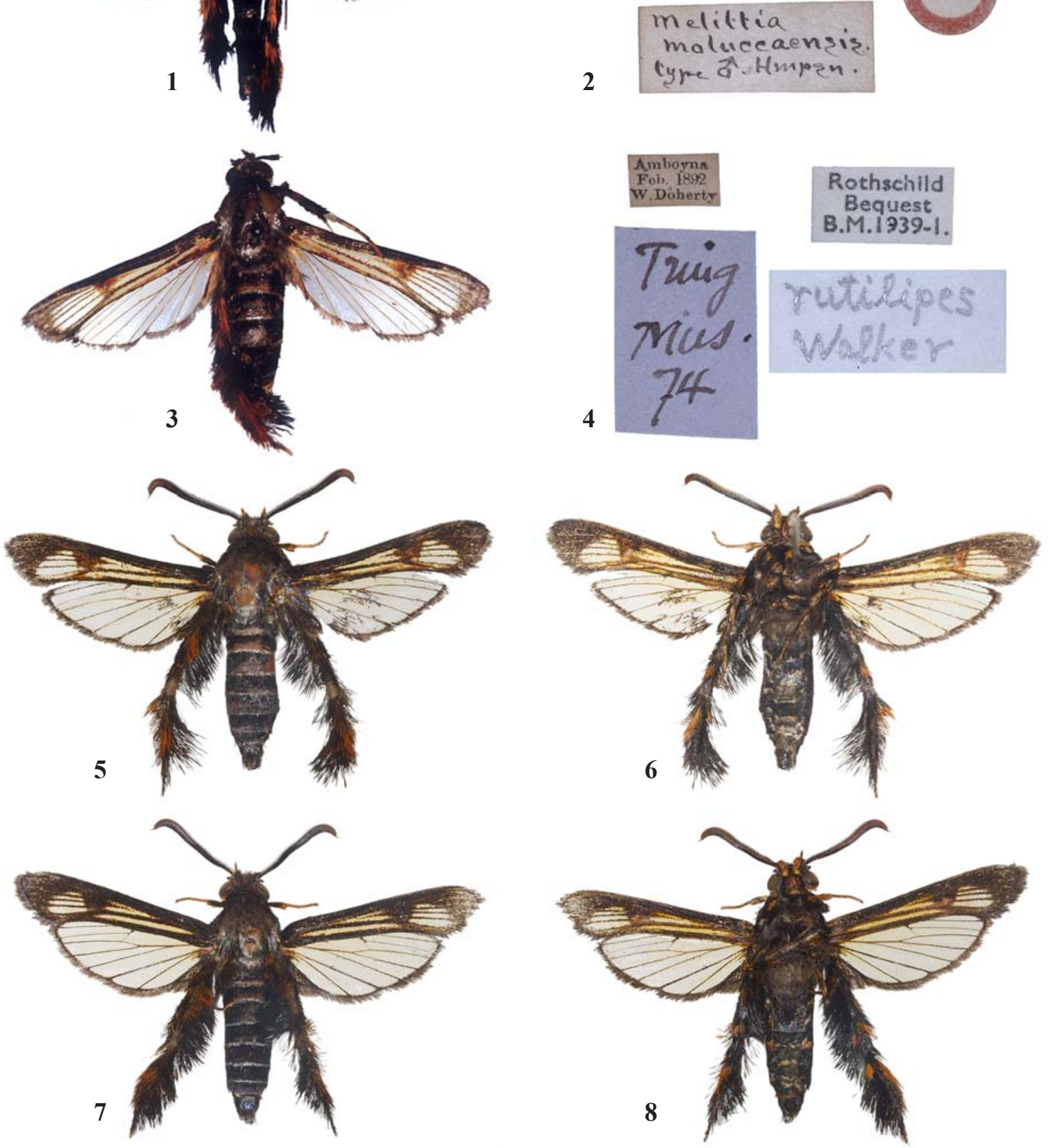

Figs 1-8. Variability of Melittia rutilipes: $1-\mathrm{O}^{7}$, holotype of M. moluccaensis; 2 - ditto, labels; 3 - $; 4$ - ditto, labels; 5-6 - $0^{7}$, Indonesia, North Maluku, Bacan Id., Labuha, $00^{\circ} 39.390^{\prime} \mathrm{N}, 127^{\circ} 30.042^{\prime} \mathrm{E}, 118 \mathrm{~m}$, 28.II.2017, O. Gorbunov leg. (Sesiidae pictures №№ 0009-

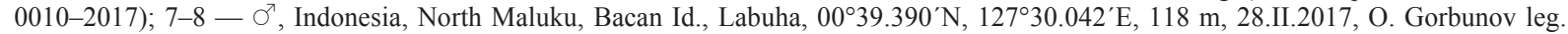
(Sesiidae pictures №№ 0011-0012-2017).

Рис. 1-8. Изменчивость Melittia rutilipes: 1 - ○', голотип M. moluccaensis; 2 - то же, этикетки; 3 - $;$; 4 - то же, этикетки; 5-

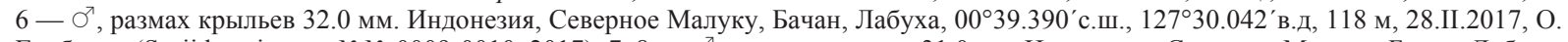
Горбунов (Sesiidae pictures №№ 0009-0010-2017); 7-8 - О7, размах крыльев 31.0 мм. Индонезия, Северное Малуку, Бачан, Лабуха, 00³9.390' с.ш., $127^{\circ} 30.042^{\prime}$ в.д, 118 м, 28.II.2017, О. Горбунов (Sesiidae pictures №№ 0011-0012-2017). 
distal row of scales of sternites 3,4 and 7 with a few pale yellow scales; anal tuft extremely small, black with dark violet sheen.

Male genitalia (Figs 9-10) (genital preparation № OG054-2018). Tegumen-uncus complex relatively broad; uncus bilobed distally with a relatively large oval plate of strong pointed setae internally and a group of setae ventrally on each side; gnathos rather small, membranous, with weakly-sclerotized semi-oval, pointed apically, plate (Fig. 9); valva (Fig. 9) trapeziform; distal field of setae not separated from medial one; setae of medial field relatively long, reaching pocketshaped crista; ventral lobe relatively narrow and long, only slightly exceeds distal margin od valva; pocket-shaped crista relatively narrow; saccus narrow, slightly broadened subbasally and rounded; aedeagus (Fig. 10) narrow, slightly shorter than valva; vesica with numerous minute cornuti.

Female (holotype of Melittia rutilipes) [see fig. 7 in Arita, Gorbunov, 1995]. Alar expanse $35.0 \mathrm{~mm}$; body length $17.0 \mathrm{~mm}$; forewing $15.5 \mathrm{~mm}$; antenna $7.5 \mathrm{~mm}$.

Head with antenna ventrally light brown with a few, thin, yellow scales subapically; frons with a few orange scales laterally; pericephalic hairs black dorsally and orange laterally; thorax with patagia with a small orange spot laterally; forewing with costal margin with a narrow, longitudinal, orange line; $\mathrm{Cu}$-stem and anal margin black mixed with orange; apical area orange; transparent areas small; anterior transparent area hyaline only at posterior half; external transparent area densely covered with slightly darkened, semitransparent scales, divided into three cells; Hindwing with anal lobe orange mixed with black; veins and discal spot orange; abdomen dorsally with a few rusty-orange scales on 3 rd and 5th tergites; tergites 2, 4 and 6 each with a narrow, orange-yellow, distal margin; tergites 3 and 5 each with a few yellowish scales on distal margin; ventrally sternites 3-6 each with a narrow, yellow, distal margin; anal tuft small, black with yellow-orange scales distally. Otherwise colour pattern as in male.

Female genitalia (genital preparation № GA-092) [see figs 22 and 26 in Arita, Gorbunov, 1995].

INDIVIDUAL VARIABILITY. The second female known to me (Fig. 3), has more large external transparent area of the forewing, which is divided into 5-6 cells and the outer margin of the hindwing is more narrow. The females are invariable in the colouration and in the conformation of the wings. They are slightly variable in the individual size: Alar expanse $31.0-32.0 \mathrm{~mm}$, body length $16.8-17.5 \mathrm{~mm}$, forewing 13.2-13.5 mm, antenna $6.9-7.1 \mathrm{~mm}$.

DIFFERENTIAL DIAGNOSIS. By the shape of the discal spot and anterior transparent area of the forewing this species cannot be confused with any congeners, but it is probably closest to Desmopoda bombiformis Felder et Felder, 1874 (it is quite possible that Desmopoda is a junior synonym

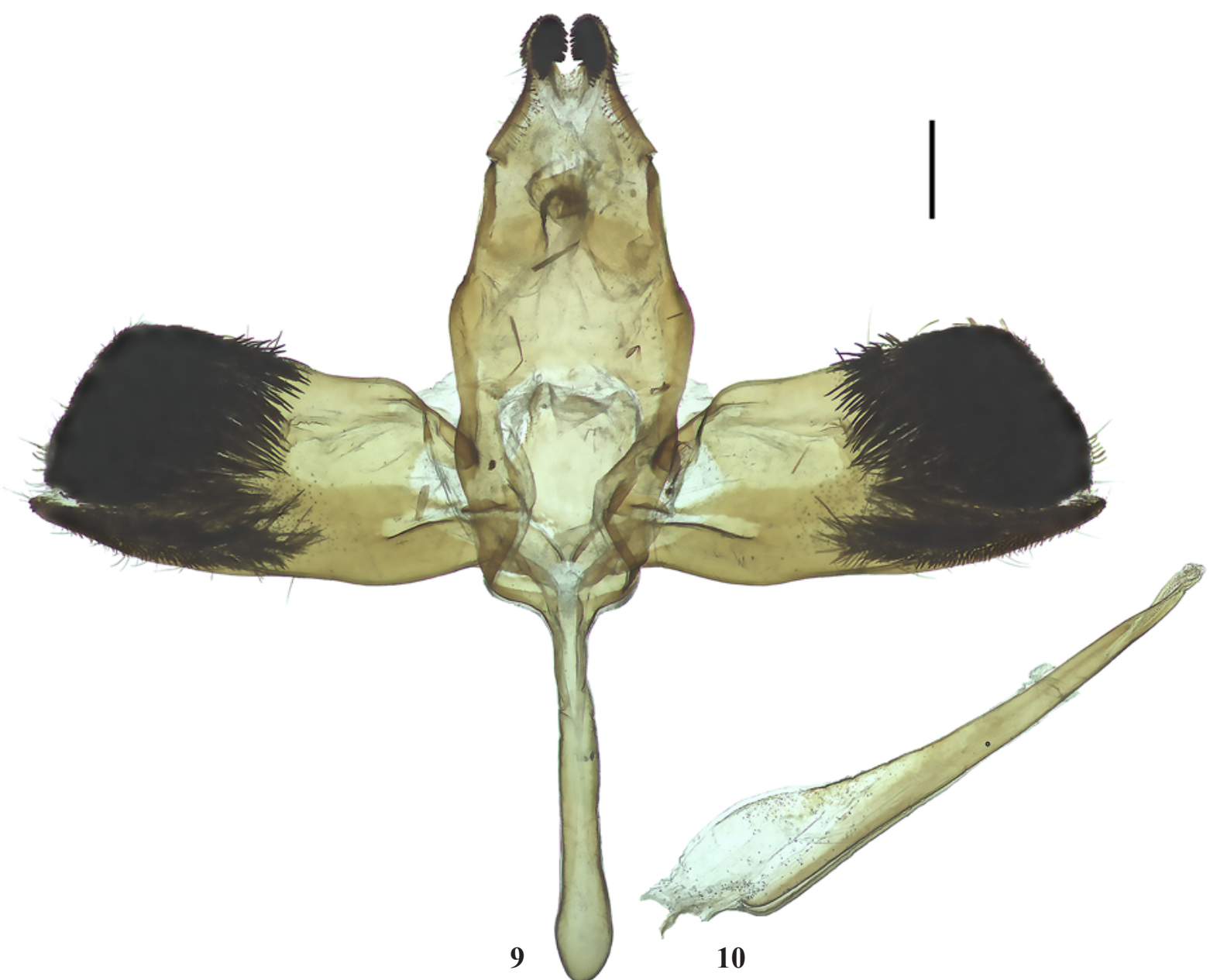

Figs 9-10. Male genitalia of Melittia rutilipes, genital preparation № OG-054-2018: 9 — general view; 10 — aedeagus. Scale bar: 0.5 mm. Рис. 9-10. Гениталии самца Melittia rutilipes, препарат гениталий № OG-054-2018: 9 — общий вид; 10 — эдеагус. Масштаб: 0,5 мм. 
of Melittia, as stated earlier [Arita, Gorbunov, 1995]), but can be distinguished by a somewhat smaller size (alar expanse $44.0 \mathrm{~mm}$ in the species compared) and coloration of the hind leg tuft (with orange, yellow and brown-orange scales in the species compared; see tab. 75, fig. 5 in Felder, Felder, 1874 ) and forewing (without orange or brown-rusty scales in D. bombiformis). In addition, it should be noted that the presence of setae on the uncus of the male genitalia is unique among all Melittia species for which the male genitalia are known.

BIONOMICS. The larval host-plant is unknown. The freshly collected specimens were attracted by unspecifical artificial sex pheromones. They came to lures in the afternoon around 2-3 pm. Specimens from Bacan and Ambon were collected on February.

HABITAT. In the island of Bacan, North Maluku, this species was collected on a clearing among the secondary rainforest in the vicinity of the town of Labuha (Fig. 11).

DISTRIBUTION. Known from the islands of Bacan (North Maluku) and Buru and Ambon (Maluku), Indonesia.

Acknowledgements. I would like to express my cordial thanks to Mr. Maxim B. Markhasyov, Dr. Vasily K. Tuzov and Prof. Dmitry G. Zamolodchikov (all from Moscow, Russia) for the company and help during our successful trip to North Maluku, Indonesia in 2017. I also wish to thank Prof. Yutaka Arita (Iga, Mie, Japan) for providing slides of the type specimens of the clearwing moth deposited in European collections. I am indebted to Mr. Vlad Proklov (London, England) for carefully checking the English of an advanced draft.
The study was conducted using the equipment of the Joint Usage Center "Instrumental methods in ecology" at the A.N. Severtsov Institute of Ecology and Evolution, Russian Academy of Sciences (Moscow, Russia).

\section{References}

Arita Y., Bae Y.S., Lee C.M., Ikeda M. 2004. Sesiidae (Lepidoptera) of Korea // Trans. Lepid. Soc. Japan. Vol.55. No.1. P.1-12.

Arita Y., Gorbunov O.G. 1995. A revision of the Melittia types (Lepidoptera, Sesiidae) kept in the Hope Entomological Collections, Oxford University, UK // Trans. Lepid. Soc. Japan. Vol.46. No.4. P.185-205.

Arita Y., Gorbunov O.G. 1996a. New and unrecorded clearwing moths of the genus Melittia Hübner, [1819] (Lepidoptera, Sesiidae) from Thailand // Trans. Lepid. Soc. Japan. Vol.47. No.3. P.157-173.

Arita Y., Gorbunov O.G. 1996b. A revision of Ferdinand Le Cerf's clearwing moth types (Lepidoptera, Sesiidae), kept at the Paris Museum. I. The genus Melittia Hübner [1819] in the Oriental and Australian Regions // Jpn. J. syst. Ent. Vol.2. No.2. P.137-187.

Arita Y., Gorbunov O.G. 1997. Description of a new Melittia clearwing moth (Lepidoptera, Sesiidae) from Kyushu, Japan // Trans. Lepid. Soc. Japan. Vol.48. No.1. P.33-38.

Arita Y., Gorbunov O.G. 2000. On the tribe Melittiini (Lepidoptera, Sesiidae) of Vietnam // Tinea. Vol.16. No.4. P. 252-291.

Arita Y., Gorbunov O.G. 2001. A revision of C. Aurivillius' clearwing moth types of the tribe Melittiini (Lepidoptera, Sesiidae) // O.G. Gorbunov (ed.). Melittia, Lepid. Almanac. Vol.1. P.53-59.

Arita Y., Gorbunov O.G. 2002. Sesiidae of Taiwan. II. The tribes Osminiini, Melittiini and Sesiini // Jpn. J. syst. Ent. Vol.8. No.2. P.199-241.

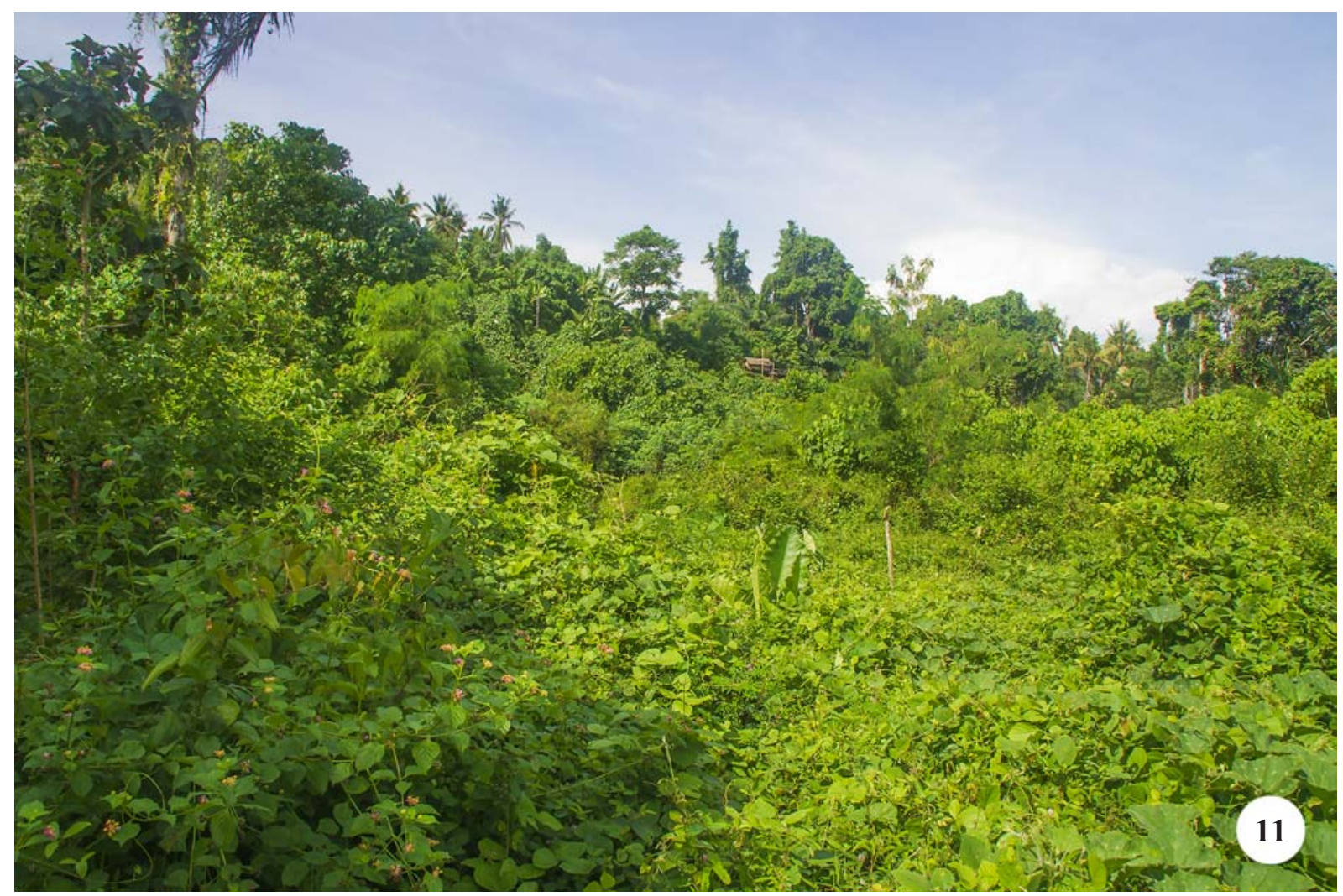

Fig. 11. Habitat of Melittia rutilipes. Indonesia, North Maluku, Bacan Id., Labuha, $00^{\circ} 39.390^{\prime} \mathrm{N}, 127^{\circ} 30.042^{\prime} \mathrm{E}, 118 \mathrm{~m}, 28 . \mathrm{II} .2017$. Рис. 11. Биотоп Melittia rutilipes. Индонезия, Северное Малуку, Бачан, Лабуха, 00³9.390' с.ш., $127^{\circ} 30.042$ 'в.д, 118 м, 28. II.2017. 
Arita Y., Kallies A. 2000. A new and an unrecorded species of Melittia (Lepidoptera, Sesiidae) from North Vietnam // Trans. Lipid. Soc. Japan. Vol.52. No.1. P.51-57.

Arita Y., Yata N. 1987. Descriptions of two new species of Melittia (Lepidoptera: Sesiidae) of Japan // Tinea. Vol.12 (Suppl.). P.158-167.

Bartel M. 1912. 24. Familie: Aegeriidae (Sesiidae) // Seitz A. (Hrsg.). Die Gros-Schmetterlinge der Erde. Bd.2. Die Palaearktischen Spinner \& Schwärmer. Stuttgart: A Kernen Verlag. S.375-416. P1.51-52.

Bartsch D. 2016. Melittia fiebigi spec. nov. and Afromelittia caerulea spec. nov., two new Melittiini from southern Africa (Lepidoptera: Sesiidae) // Ann. Ditsong Nat. Mus. Nat. Hist. Vol.6. P.109-115.

Boisduval J.A. 1875. Sphingides, Sésiides, Castnides // Boisduval J.A. Guénée A. Histoire Naturelle des Insectes. Species général des Lépidoptères Hétérocères. Vol.1. Paris: Roret. iv+568 pp. 11 pls.

Dalla Torre K.W., Strand E. 1925. Aegeriidae // E. Strand (Hrsg.) Lepidopterorum Catalogus. Bd.31. Berlin: W. Junk. 202 S.

Felder R., Felder C. 1874. Lepidoptera: atlas // C. Felder, R. Felder, A.F. Rogenhofer (Hrsg.) Reise der Österreichischen Fregatte Novara um die Erde in den Jahren 1857, 1858, 1859 unter den Befehlen des Commodore B. von Wüllerstorf- Urbair. Zoologischer Theil. 2(2). No.4. Wien: Kaiserlich-Königliche Hof- und Staatsdruckerei. S.1-10. P1.75-107.

Gaede M. 1929. 22. Familie: Aegeriidae (Sesiidae) // A. Seitz (Hrsg.), Die Gross-Schmetterlinge der Erde. Bd.14. Die afrikanischen Spinner und Schwärmer. Stuttgart: A. Kernen Verlag. S.515-538. P1.77.

Gaede M. 1933. 23. Familie: Aegeriidae // Seitz A. (Hrsg.). 19261930. Die Gross-Schmetterlinge der Erde. Bd.10. Die indoaustralischen Spinner und Schwärmer. Stuttgart: A. Kernen Verlag. S.775-802. P1.94-95.

Gorbunov O.G. 2014. A new species of the genus Melittia Hübner, 1819 ["1816"] from the island of Lombok, Indonesia // Far Eastern Entomologist. No.284. P.13-18.

Gorbunov O.G. 2015. Contributions to the study of the Ethiopian Lepidoptera. I. The genus Melittia Hübner, 1819 ["1816"] with description of a new species // Zootaxa. Vol.4033. No.4. P. 543 554

Gorbunov O.G. 2017. On the taxonomy and morphology of Leuthneria ruficincta (Lepidoptera, Sesiidae) // Zootaxa. Vol.4244. No.1. P.127-136.

Gorbunov O.G., Arita Y. 1995. New taxa of the tribe Melittiini (Lepidoptera, Sesiidae) from the Oriental Region // Tinea. Vol.14. No.3. P.149-156.

Gorbunov O.G., Arita Y. 1996. New and little-known Oriental Melittia Hübner (Lepidoptera, Sesiidae), from the collection of
Muséum d'histoire naturelle, Genève // Revue suisse Zool. T.103. Fasc.2. P.323-338.

Gorbunov O.G., Arita Y. 1997. A revision of Ferdinand Le Cerf's clearwing moth types (Lepidoptera, Sesiidae), kept at the Paris Museum. II. Melittiini in the Afrotropical Region // Jpn. J. syst. Ent. Vol.3. No.2. P.289-323.

Gorbunov O.G., Arita Y. 1999. Three new taxa of the genus Melittia Hübner, [1819] (Lepidoptera, Sesiidae) from India // Trans. Lepid. Soc. Japan. Vol.50. No.3. P.193-208.

Hampson G.F. 1919. A classification of the Aegeriadae [sic] of the Oriental and Ethiopian Regions // Novitates Zoologicae. Vol.26. No.1. P.46-119.

Heppner J.B., Duckworth W.D. 1981. Classification of the Superfamily Sesioidea (Lepidoptera, Ditrysia) // Smithsonian Contr. Zool. Vol.314. P.1-144.

Kallies A., Arita Y. 2003. A note on the genus Melittia Hübner from New Guinea, with the description of a new species, Melittia propria sp. nov. (Lepidoptera, Sesiidae) // Tinea. Vol.17. No.4. P.173-175.

Kallies A., Arita Y. 2004. New taxa and records of clearwing moths of the tribe Melittiini (Lepidoptera, Sesiidae) from Vietnam // Jpn. J. syst. Ent. Vol.10. No.2. P.193-209.

Kallies A., Arita Y., Min W. 2016. A new species and new records of Melittiini from China and Vietnam (Lepidoptera, Sesiidae) // Zootaxa. Vol.4205. No.2. P.162-170.

Liang J.-Y., Hsu Y.-F. 2017. Two new species of clearwing moths (Lepidoptera: Sesiidae) from Taiwan // Zootaxa. Vol.4299. No.3. P.415-422.

Moreira G.R.P., Gorbunov O.G., Fochezato J., Gonçalves G.L. 2019 A peculiar new species of gall-inducing, clearwing moth (Lepidoptera, Sesiidae) associated with Cayaponia in the Atlantic Forest // ZooKeys. Vol.866. P.39-63.

Nye I.W.B. 1975. The generic names of moths of the world. Vol.1. Noctuidae (part): Noctuidae, Agaristidae, and Nolidae. London: Trustees of the British Museum (Natural History). 568 pp.

Pühringer F., Kallies A. 2004. Provisional checklist of the Sesiidae of the world (Lepidoptera: Ditrysia) // Mitt. Ent. Arb. gem. Salzkammergut. Bd.4. P.1-85.

Špatenka K., Gorbunov O., Laštùvka Z., Toševski I., Arita Y. 1999. Sesiidae, Clearwing Moths // C.M. Naumann (Ed.). Handbook of Palaearctic Macrolepidoptera. Vol.1. Wallingford: Gem Publishing Company. 569 pp., 57 pls.

Swinhoe C., 1892. Sphinges and Bombyces // Catalogue of Eastern and Australian Lepidoptera Heterocera in the Collection of the Oxford University Museum. Vol.1. Oxford: Clarendon Press. viii +324 pp., 8 pls.

Walker F. 1865. List of the specimens of Lepidopterous Insects in the collection of the British Museum. Supplement 31 (Suppl.1). London: Trustees of the British Museum (Natural History). 321 pp. 